\title{
GENETIC ETIOLOGY OF PRIMARY PREMATURE OVARIAN INSUFFICIENCY
}

\author{
Maja Franić-Ivanišević ${ }^{1}$, Damir Franić ${ }^{2,3}$, Miomira Ivović ${ }^{4}$, Milina Tančić-Gajić ${ }^{4}$, \\ Ljiljana Marina ${ }^{4}$, Marija Barac ${ }^{4}$ and Svetlana Vujović ${ }^{4}$
}

${ }^{1}$ University Department of Gynecology and Obstetrics, Clinical Center of Serbia, Belgrade, Serbia; ${ }^{2}$ Outpatient Clinic for Obstetrics and Gynecology, Rogaška Slatina; ${ }^{3}$ School of Medicine, University of Maribor, Maribor, Slovenia; ${ }^{4}$ University Department of Endocrinology, Clinical Center of Serbia, Belgrade, Serbia

\begin{abstract}
SUMMARY - Primary premature ovarian insufficiency (PPOI) is characterized by hypergonadotropic amenorrhea and hypoestrogenism in women under 40 years of age. PPOI incidence is 1:10,000 in women aged 18-25, 1:1000 in women aged 25-30 and 1:100 in women aged 35-40. In 10\%-28\% of cases, PPOI causes primary and in $4 \%-18 \%$ secondary amenorrhea. The process is a consequence of accelerated oocyte atresia, diminished number of germinated cells, and central nervous system aging. Specific genes are responsible for the control of oocyte number undergoing the ovulation process and the time to cessation of the reproductive function. A positive family history of PPOI is found in 15\% of women with PPOI, indicating the existing genetic etiology. Primary POI comprises genetic aberrations linked to chromosome $\mathrm{X}$ (monosomy, trisomy, translocation, deletion) or to autosomal chromosome. Secondary POI implies surgical removal of ovaries, chemotherapy and radiotherapy, and infections. Diagnostic criteria include follicle stimulating hormone level $>40 \mathrm{IU} / \mathrm{L}$ and estradiol level $<50 \mathrm{pmol} / \mathrm{L}$.
\end{abstract}

Key words: Primary ovarian insufficiency - etiology; Primary ovarian insufficiency - genetics

\section{Introduction}

Premature ovarian insufficiency (POI) is characterized by hypergonadotropic amenorrhea and hypoestrogenism in women under 40 years of age. Diagnostic criteria are follicle stimulating hormone (FSH) level $>40 \mathrm{IU} / \mathrm{L}$ and estradiol (E2) level $<50 \mathrm{pmol} / \mathrm{L}^{1}$. The POI incidence is $1: 10,000$ in women aged 18-25, 1:1000 in women aged $25-30$ and $1: 100$ in women aged $35-40^{2}$. POI causes $10 \%-28 \%$ of primary amenorrhea and $4 \%-18 \%$ of secondary amenorrhea ${ }^{3}$. The onset of the disease is a consequence of an accelerated process of oocyte atresia, i.e. a diminished number of germinated cells, and maturation of the central ner-

Correspondence to: Assist. Prof. Damir Franic, $M D, P h D$, Ginekologija dr. Franić d.o.o., Celjska c. 10, 3250 Rogaška Slatina, Slovenia

E-mail: damir.franic@guest.arnes.si

Received June 6, 2016, accepted June 26, 2016 vous system. Specific genes are responsible for the control of oocyte number undergoing ovulation process and cessation of the reproductive period ${ }^{4}$. A positive family history of POI was found in $15 \%$ of women with POI, confirming the existing genetic etiology $y^{5,6}$.

Before the $20^{\text {th }}$ week of gestation, the meiosis and mitosis processes go in parallel in the ovary and after that time, maturation and distribution of the future oocytes is completed. The number of oocytes is limited at birth; therefore, there will be no further production of this cell type. The maximum number of primordial follicles in the female fetus increases in 20-24 weeks of gestation, when the process of atresia starts. In the process of cessation, the number of primordial follicles decreases from 6-7 million to 1-2 million at birth, then to $300,000-400,000$ on entering puberty. The ongoing process of steroidogenesis takes place up to the last follicle exists. It is well known that typical climacteric symptoms start when the number of primordial folli- 
cles decreases below 2500 in both ovaries. The increase in FSH starts shortly after age 30, while the number of the rest of the follicles correlates with further FSH increase after age 40 .

Difference between the primordial and primary follicles is determined by layers of granulosa cells surrounding oocytes, with one layer in primordial follicles and multiple layers of cuboid granulosa cells in primary follicles. One of the possible etiologic factors for primary POI might be a disorder at the level of transmission from primordial to primary follicles.

Every woman younger than 40 with amenorrheic period is obliged to seek help at the gynecologist office. Symptoms of POI are psychological (nervousness, hot flushes, excitability, insomnia, depression, loss of libido, lack of concentration) and physical (parts of body feeling numb or tingling, muscle or joint pains, body weight increase). Hormone analysis (FSH, luteinizing hormone (LH), estradiol (E2), antimüllerian hormone $(\mathrm{AMH})$, inhibin $\mathrm{B}$, prolactin, progesterone, testosterone, free thyroxine (fT4) and thyroid-stimulating hormone (TSH)) is necessary. POI diagnosis is confirmed by FSH $>40 \mathrm{IU} / \mathrm{L}$ and estradiol $<50 \mathrm{pmol} / \mathrm{L}$ in women aged $<40$. When Addison's disease is suspected, adrenocorticotopic hormone (ACTH) stimulation test is performed. Karyotyping is necessary in women younger than 30. Ovarian biopsy is not a routine procedure. Dual energy $\mathrm{x}$-ray absorptiometry is recommended in screening for osteoporosis.

\section{Etiology}

Premature ovarian insufficiency is divided into two main groups: primary POI (PPOI) and secondary POI (SPOI). The etiology of PPOI is shown in Table 1.

\section{Genetic Causes}

\section{Follicle-stimulating hormone receptor gene mutation}

In some families, familial PPOI occurrence is figured out (grandmother, mother and daughter) earlier in every consecutive generation. One of the possible causes is a mutation in the FSH receptor gene. Inactivated mutation of the FSH receptor (FSHR) gene damages adenylyl cyclase stimulation, while the receptor remains captured inside the cell. FSH is essential for normal follicle maturation. In the last 50 days of its
Table 1. Etiology of primary premature ovarian insufficiency

\begin{tabular}{|c|c|}
\hline Genetic causes & $\begin{array}{l}\text { - FSH receptor mutation, } \\
\text { transcription factor mutation } \\
\text { - Fragile X chromosome } \\
\text { - Structural alteration and } \\
\text { monosomy of the X chromosome } \\
\text { - Chromosome X trisomy with or } \\
\text { without mosaicism } \\
\text { - Myotonic dystrophy }\end{array}$ \\
\hline $\begin{array}{l}\text { Enzyme } \\
\text { deficiency }\end{array}$ & $\begin{array}{l}\text { - } 17 \alpha \text { hydroxylase deficiency } \\
\text { - Galactosemia }\end{array}$ \\
\hline $\begin{array}{l}\text { Gonadotropin } \\
\text { structure/acting } \\
\text { deficiency }\end{array}$ & $\begin{array}{l}\text { - Biologically inactive gonadotropin } \\
\text { - } \alpha \text { and } \beta \text { subgroup deficiency } \\
\text { - Receptor/post-receptor deficiency }\end{array}$ \\
\hline Idiopathic & - Unknown cause \\
\hline
\end{tabular}

development, maturation of the follicle is blocked. A large number of small follicles with no ability to progress further are present in women with PPOI. The most frequent mutation is present in exon 7 of the FSHR gene (FSHR, located on $2 \mathrm{p}$ chromosome), replacing Ala to $\mathrm{Val}$ at protein level. Mutations of the FSHR gene are related to FSH resistance, which leads to an increased FSH level and a decreased estrogen serum level. Women with total FSH resistance have hypoplastic ovaries and primary amenorrhea ${ }^{7}$. Some other forms of FSHR have been identified in women with PPOI and secondary amenorrhea, moderate ovary dysfunction and family history of $\mathrm{PPOI}^{8}$. These variances are rare and there is no direct influence in the etiology of $\mathrm{PPOI}^{9,10}$.

\section{Structural alterations of chromosome}

$\mathrm{X}$ chromosome alterations are the most frequent genetic causes of PPOI, accounting for $12 \%$ of cas$\mathrm{es}^{6,11-13}$. These alterations comprise complete monosomy or partial deletion, duplication or translocation of the $\mathrm{X}$ chromosome, as follows:

a) Turner syndrome (45X0) - the prevalence of $\mathrm{X}$ monosomy is 1:2500. Turner syndrome is characterized by lower height than normal, gonadal dysgenesis and primary amenorrhea ${ }^{14}$. Oocyte deprivation begins mainly in the early childhood as a consequence of accelerated follicle atresia ${ }^{14}$.

b) Trisomy X (47 XXX) - usually does not cause particular problems, but in some cases PPOI 
appears $^{15}$. The genes located on the X chromosome are critical for the normal function of the ovary, thus any abnormality can induce $\mathrm{PPOI}^{9,16}$. Groswani et al. ${ }^{17}$ found that $3.8 \%$ of women with PPOI had X chromosome trisomy.

c) Fragile $\mathrm{X}$ chromosome - expansion of trinucleotide tandem repeat CGG at the 5'UTR region of the FMR 1 gene (Xq27.3) was found in some PPOI cases. The CGG tandem repeat variation length is defined as normal $(\leq 50)$, premutation (50-200) and full mutation ( $\geq 200$ tandem repeats). Full mutation is associated with a fragile $\mathrm{X}$ syndrome, where mental retardation is the crucial $\operatorname{sign}^{18}$. Recently, some epidemiological studies have found connection of the premutation FMR1 gene with PPOI in 6\% of sporadic cases and $13 \%$ of family PPOI ${ }^{19}$. FMR 1 protein is expressed in fetal germ cells, as well as in granulosa cells of the mature follicle ${ }^{20}$.

The carriers of the premutation alleles can exhibit 3 clinical forms, i.e. PPOI; lack of concentration/attention and other psychological changes; and neurologic disorders (tremor, ataxia, Parkinson's disease).

Hegerman et al. ${ }^{21}$ indicated the association of PPOI with tremor, ataxia and Parkinson's disease, which could be one more proof of the important role of sex steroids in the brain.

In the most prominent number of cases, PPOI seems to be a multifactorial disorder. From this point of view, studies of the gene-DNA polymorphism are crucial in clarifying PPOI etiology. DNA or gene polymorphisms express the variants in hereditary basis, which could be found in the general population. From the phenotype point of view, they are in principle 'benign', but could also represent predisposition for certain, usually multifactorial disorders ${ }^{22}$.

Polymorphisms in the genes encoding steroid hormone receptors, as well as their connection with different reproductive system disorders have been intensively studied in the last few years. It is well known that the forehand expression and proper coordination of the genes are fundamental for the normal growth and development of the ovary ${ }^{23}$. Polymorphisms important for PPOI are mostly unknown despite of the pathogenic defects identified in some candidate genes ${ }^{24,25}$. Therefore, in most PPOI cases, no clear etiologic factors were found, so they were classified as idiopathic PPOI.

\section{Oocyte-specific transcription factors}

In homozygous FOXL2 mutation, granulosa cells do not undergo transition from squamous to cuboid, and it is exactly the layer where the mistake comes from. This is the reason for the absence of secondary follicles, so oocyte atresia occurs ${ }^{26}$. The genes specifically expressed in oocyte are regulated through the specific transcription factors ${ }^{12}$. Mutations are identified in several genes encoding transcriptional factors important for folliculogenesis, i.e. NRA1, NOBOX, FIGLA and FOXL227-29.

Nuclear Receptor subfamily fifth group term 1 (NR5A1), known as steroidogenic factor 1 , is a nuclear receptor which is implicated in early gonadal differentiation $^{29,30}$. The NR5A1 gene is_located at 9q33.3. Steroidogenesis is modulated through the regulation of the genes involved in the hypothalamic-pituitary-steroidogenetic axis, such as: STAR, CYP11A1, CYP17A1, CYP19A1, LH and INHA ${ }^{30}$.

Homeobox protein (NOBOX) - the newborn ovary homeobox gene is an oocyte - is a specific expressed gene with an essential role in folliculogenesis and so one of the candidate genes for $\mathrm{PPOI}^{28}$. It is responsible for the specific transcriptional factor which regulates the genes important for early folliculogenesis ${ }^{31}$. Using the knockout mouse model, it has been proven that NOBOX regulates different gene expressions specific for the oocyte, including BMP-15 and GDF-931. The lack of NOBOX expression is connected with accelerated oocyte loss after mouse parturition ${ }^{30}$.

Folliculogenesis Specific Basic Helix-Loop-Helix (FIGLA), the embryo-specific transcription factor, regulates expression of the genes responsible for the initiation of folliculogenesis and coding the zona pellucida proteins (ZP1, ZP2 and ZP3) essential for fecundation and embryo survival. It is crucial for oocyte rebellion and formatting the primordial follicles ${ }^{32}$. Its lack leads to accelerated loss of postnatal primordial follicles in mice ${ }^{33}$.

Forkhead Box L2 (FOXL2) gene is located on $3 \mathrm{q} 23$. Foxl2 protein exudes in the granulosa cells from the embryogenesis until the adult age ${ }^{27}$. The mutation of this gene leads to failure of granulosa cell differentiation, which induces early activation and exhaustion of primordial follicles ${ }^{33}$. The FOXL2 mutation is identified in 5\% of non-syndromic PPOI patients, suggesting the possibility of idiopathic PPOI occurrence ${ }^{27}$. 
Helix-loop-helix (SOHLH) 1 and 2 are transcription factors important for PPOI. They are responsible for the follicle early growth and differentiation by control of a number of genes including NOBOX, FIGLA, BMP-15 and GDF-912. The SOHLH2 gene is located on chromosome 13. This gene codes one of the factors which are crucial for spermatogenesis, oogenesis and folliculogenesis ${ }^{12}$. Zhao et al. ${ }^{34}$ found three new SOHLH1 variations as the potential cause of PPOI in 364 Chinese women with PPOI.

\section{Folliculogenesis growth factors}

Bone morphogenetic protein 15 (BMI-15) is a member of the transforming growth factor $ß$ (TGF- $\beta$ ) superfamily. The gene is located at $\mathrm{Xq} 11.2$ and encodes an oocyte-specific growth and differentiation factor ${ }^{35}$. BMP-15 is involved in stimulating folliculogenesis and promoting follicle maturation by regulating granulosa cell differentiation and proliferation ${ }^{36}$.

The growth differentiation factor 9 (GDF9) gene, a homologue of BMP-15, is also member of the TGF- $\beta$

Table 2. Some of the gene candidates and their function in the pathogenesis of primary premature ovarian insufficiency

\begin{tabular}{|c|c|c|}
\hline Gene & Gene locus & Function of a gene product \\
\hline FMR1 & $\mathrm{Xq} 27.3$ & $\begin{array}{l}\text { Oocyte development } \\
\text { and maturation }\end{array}$ \\
\hline NR5A & $9 \mathrm{q} 33.3$ & Steroidogenesis of the ovary \\
\hline NOBOX & $7 \mathrm{q} 25$ & Early folliculogenesis \\
\hline FIGLA & $2 \mathrm{q} 12$ & $\begin{array}{l}\text { Zona pellucida gene } \\
\text { regulation }\end{array}$ \\
\hline FOXL2 & $3 \mathrm{q} 23$ & $\begin{array}{l}\text { Granulosa cell } \\
\text { differentiation and follicle } \\
\text { development }\end{array}$ \\
\hline SOHL1/2 & $13 q 13.3$ & Early folliculogenesis \\
\hline BMP-15 & Zq11.2 & Follicular maturation \\
\hline GDF-9 & $5 \mathrm{q} 23.2$ & Follicular maturation \\
\hline INHA & $2 q 33-36$ & $\begin{array}{l}\text { Folliculogenesis regulation } \\
\text { via FSH inhibition }\end{array}$ \\
\hline FSHR & $2 \mathrm{p} 21$ & $\begin{array}{l}\text { Growth and development } \\
\text { of the follicle, } \\
\text { steroidogenesis }\end{array}$ \\
\hline LHR & $2 \mathrm{p} 21$ & $\begin{array}{l}\text { Follicle maturation, } \\
\text { steroidogenesis, ovulation }\end{array}$ \\
\hline ESR1 & $6 \mathrm{q} 25.1$ & $\begin{array}{l}\text { Growth and development } \\
\text { of the follicle }\end{array}$ \\
\hline
\end{tabular}

superfamily and is located at 5q23.2. Like BMP-15, GDF-9 is oocyte specific and regulates primordial follicle development and stimulates granulosa cell proliferation and follicle maturation ${ }^{30}$. GDF-9 is also thought to play a role in steroidogenesis and modulation of FSH sensitivity in granulosa cell ${ }^{37}$.

Inhibin alpha (INHA) gene encodes the alpha subunit of inhibin $\mathrm{A}$ and inhibin $\mathrm{B}$, which together with their corresponding beta units (INHBA and INHBB), a class of dimeric glycoproteins, also belong to the TGF- $\beta$ superfamily ${ }^{38}$. Inhibins are produced primarily by granulosa cells and act on the pituitary by inhibiting FSH production ${ }^{39}$. Decreased inhibin production is associated with increased FSH production, leading to enhanced follicle recruitment and increased depletion of the follicular pool ${ }^{11}$. Indeed, women with idiopathic POI have lower serum levels of inhibins and higher serum FSH as compared with age-matched fertile controls, suggesting that inhibins play an important role in normal ovarian function ${ }^{39}$.

Some of the gene candidates and their function in the pathogenesis of PPOI are shown in Table $2^{40}$.

\section{Receptors}

\section{Estrogen receptors}

Estrogen receptors (ER) are transcriptional factors that occur in granulosa cells, as well as in many other tissues and are involved in the expression of different genes included in the cell growth and development ${ }^{41}$. There are two estrogen receptors known as ERa and $\mathrm{ERb}$. Estrogen regulates gonadotropin release via ERa action, labeled with ESR1 on the hypothalamic-hypophyseal axis ${ }^{42}$. The ERa gene is located on 6q25-27 chromosome. Its promoter area comprises a polymorphic chain TA tandem repeat, associated with hereditary premature ovarian dysfunction, as well as with diminished bone mineral density and endometriosis.

The ER $\beta$ gene is located on the $14 \mathrm{q} 23-24$ chromosome. Estrogen improves folliculogenesis via $\mathrm{ER} \beta^{42}$. On uncoding 3'-region of this gene, a polymorphic CA tandem repeat chain was recently identified, speculating about its connection with bone mineral density in women ${ }^{43}$. The functional role of these two polymorphisms has not yet been fully clarified; however, there is some evidence for their influence on the structure and function of the genes ${ }^{44}$. The connection between 
these two microsatellite polymorphisms and PPOI has been demonstrated ${ }^{45,46}$.

\section{Progesterone receptor}

The progesterone receptor (PGR) gene is situated on the $11 \mathrm{q} 22$ chromosome. A number of polymorphic regions have been discovered in this gene, and one of the functionally most important is the insertion/deletion of ALu sequence of $306 \mathrm{bp}$. It is believed that the insertion allele, labeled as PROGINS, has a protective function in the female reproductive system, either in the homozygous or heterozygous state ${ }^{47}$.

\section{Androgen receptor}

Androgen receptor (AR) belongs to the nuclear transcriptional factors family. The only AR gene is located on chromosome X, Xq11-12. In this gene, polymorphism of a different number of CAG tandem repeats encoding the polyglutaminic chain of different lengths, has been identified. This chain influences the receptor function, so that longer tandem repeats are connected with a lower functional level of the receptor $^{48}$. In fact, in the first exon of the AR gene, there are 2 microsatellite polymorphisms; the first one with CAG tandem repeats - (CAG)n and the second one with GGN tandem repeats - (GGN)n. A limited number of studies have found correlation of CAG repetitions in $\mathrm{AR}$ gene and $\mathrm{PPOI}^{49,50}$, while others did not confirm this correlation ${ }^{46,51}$. For the GGN tandem repeat in Indian women, a significant correlation with PPOI has been reported ${ }^{51}$.

\section{Enzyme Deficiency}

One of the etiologic factors for PPOI is deficiency of 17 -a hydroxylase $(17 \mathrm{OH})$, as well as galactose1-phosphate uridyltransferase (GALT). According the study by Waggoner et al., shortly after puberty, $81 \%$ of affected women develop ovarian insufficiency together with primary or secondary amenorrhea ${ }^{52}$.

Typical characteristics of women with the lack of $17 \mathrm{OH}$ are primary amenorrhea, high levels of FSH, $\mathrm{LH}$, progesterone, deoxycorticosterone, hypertension and hyperpotassium alkalosis. Intracellular accumulation of galactose metabolite or lacking glycosylation decreases germ cell reserve ${ }^{53}$.

\section{Conclusion}

Today, PPOI is considered as a multifactorial disease, where the phenotype is most probably the result of sequence variation in more than one gene. Ethnically distinct populations show differences in the generegulating pathways and genes causing PPOI.

\section{References}

1. Vujović S, Brincat M, Erel T, Gambacciani M, Lambrinoudaki I, Moen MH, et al. EMAS position statement: Managing women with POF. Maturitas. 2010;67:91-3. doi: 10.1016/j. maturitas.2010.04.011

2. Beck-Peccoz P, Persani I. Premature ovarian failure. Orphanet J Rare Dis. 2005;1(1):9.

3. Falsetti L, Scalichi S, Villant T, Bugari G. Premature ovarian failure. Gynecol Endocrinol. 1999;13:189-95.

4. Coulam CB. Autoimmune ovarian failure. Semin Reprod Endocrinol. 1983;1:161-7.

5. Van Kasteren YM, Handscheid RD, Smits AP, Cremers FP, van Zonneveld P, Bread DD. Familial idiopathic premature ovarian failure - an overrated and underestimated genetic disease. Hum Reprod. 1999;14:2455-9.

6. Dixit H, Rao L, Padmalatha V, Rareswari T, Kapu AK, Murthy $\mathrm{K}$, et al. Genes governing premature ovarian failure. Reprod Biomed Online. 2010;20:724-40. doi: 10.1016/j.rbmo.2010. 02.018

7. Abel MH, Wootton AN, Wilkins V, Huhtaniemi I, Kinght PG, Charlton HM. The effects of a null mutation in the follicle-stimulating hormone receptor gene on mouse reproduction. Endocrinology. 2000;141:1795-803.

8. Woad KJ, Prendergast D, Winship IM, Shelling AN. FSH receptor gene variants are rarely associated with premature ovarian failure. Reprod Biomed Online. 2003;26(4):396-9.

9. Woad KJ, Watkins WJ, Prendergast D, Shelling AN. The genetic basis of premature ovarian failure. Aust N Z J Obstet Gynecol. 2006;46(3):242-4.

10. $\mathrm{Pu} \mathrm{D}, \mathrm{Xing} \mathrm{Y}, \mathrm{Gao} \mathrm{Y}, \mathrm{Wu}$ J. Gene variation and premature ovarian failure - a meta-analysis. Eur J Obstet Gynecol Reprod Biol. 2014;182:226-37. doi: 10.1016/j.ejogrb.2014.09.036

11. Sheling AN, Burton KA, Chand AL, van Ee CC, France JT, Farquhar CM, et al. Inhibin: a candidate gene for premature ovarian failure. Hum Reprod. 2000;15(12):2644-9.

12. Qin Y, Jiao X, Dalgleish R, Vujovic S, Li J, Simpson LJ, et al. Novel variants in the SOHLH2 gene are implicated in human premature ovarian failure. Fertil Steril. 2014;101(4):11041109.e6. doi: 10.1016/j.fertnstert.2014.01.001

13. Groswami D, Conway GS. Premature ovarian failure. Hum Reprod. 2005;11:391-410.

14. Bianco B, Nunes Lipay MV, Guades AD, Verreschi IT. Clinical implication of the detection of the $\mathrm{Y}$ chromosome mosaicism 
in Turner's syndrome: report of 3 cases. Fertil Steril. 2008; 90(4):1197.el17-1197.e17-20. doi: 10.1016/j.fertnstert.2007. 09.014

15. Villanueva AL, Rebar RW. Triple X-syndrome and premature ovarian failure. Obstet Gynecol. 1983;62(3 Suppl):70s-73s.

16. Shelling AN. Premature ovarian failure. Reproduction. 2010; 140(5):633-41.

17. Groswami R, Groswami D, Kabra M, Gupta N, Dubey S, Dadhwal V. Prevalence of the $\mathrm{X}$ syndrome in phenotypically normal women with premature ovarian failure and its association with autoimmune thyroid disorders. Fertil Steril. 2003; 80:1052-4.

18. Sherman SL. Premature ovarian failure in the fragile $X$ syndrome. Am J Med Genet. 2000;97:189-94.

19. Allen EG, Sullivan AK, Marcus M, Small C, Dominguez C, Epstein MP, et al. Examination of reproductive aging milestones among women who carry the FMR1 premutation. Hum Reprod. 2007;22:2142-52. doi.10.1093/humrep/dem148

20. Hergersberg M, Matsuo K, Gassmann M, Schaffner W, Luccher B, Rulicke T, et al. Tissue-specific expression of a FMR1/ beta-galactosidase fusion gene in transgenic mice. Hum Mod Genet. 1995;4:359-66.

21. Hegerman RJ, Leavitt BR, Farzin F, Jacquemont S, Greco CM, Brunberg JA, et al. Fragile-X-associated tremor/ataxia syndrome (FXTAS) in females with the FMR1 premutation. Am J Hum Genet. 2004 May;75(5):1051-7. doi.10.1086/420700

22. Goswami D, Conway GS. Premature ovarian failure. Horm Res. 2007;68:196-202.

23. Simpson JL. Genetic and phenotyping heterogeneity in ovarian failure: overview of selected candidate genes. Ann N Y Acad Sci. 2008;1135:146-54.

24. Bione S, Rizzolio F, Sala C, Ricotti R, Goegan M, Manzini $\mathrm{MC}$, et al. Mutation analysis of two candidate genes for premature ovarian failure, DACH2 and POF 18. Hum Reprod. 2004;19:2759-66. doi.10.1093/humrep/deh502

25. Dixit H, Rao LK, Padmalatha W, Kanakavalli M, Deenadaval M, Gupta N, et al. Missense mutations in the BMP15 gene are associated with ovarian failure. Hum Genet. 2006;119:408-15. doi.10.1007/s00439-006-0150-0

26. Rymer J, Wilson R, Ballard K. Making decisions about hormone replacement therapy. BMJ. 2003;326:322-6.

27. Haris S, Chand A, Winship I, Geršak K, Aittomaki K, Shelling A. Identification of novel mutations in FOXL2 associated with premature ovarian failure. Mol Hum Reprod. 2002;8:729-33.

28. Qin Y, Choi Y, Zhao H, Simpson JL, Rajkovic A. NOBOX homeobox mutation causes premature ovarian failure. Am J Hum Genet. 2007;81:576-81.

29. Laurenco D, Brauner R, Lin I, De Perdigo A, Weryha G, Muresan M, et al. Mutations in NR5A1 associated with ovarian insufficiency. N Engl J Med. 2009;360:1200-10.

30. Persani L, Rossetti R, Cacciatore C. Genes involved in human premature ovarian failure. J Mol Endocrinol. 2010;45:257-79.
31. Rajkovic A, Pangas SA, Ballow D, Suzumori N, Matzuk MM. NOBOX deficiency disrupts early folliculogenesis and oocytespecific gene expression. Science. 2004;305:1157-9.

32. Zhao H, Chen ZJ, Qin Y, Shi Y, Wang S, Choi Y, et al. Transcription factor FIGLA is mutated in patients with premature ovarian failure. Am J Hum Genet. 2008;82:1342-8. doi: 10.1016/j.ajhg.2008.04.018

33. Ling I, Soyal SM, Dean I. A germ cell specific transcription factor involved in the coordinate expression of the zona pellucida genes. Development. 1997;124:4939-47.

34. Zhao H, Li G, Dalgleish R, Vujovic S, Ivanisevic M, Ivovic M, et al. Transcription factor SOHLH1 potentially associated with primary ovarian insufficiency. Fertil Steril. 2015;103(2):548553-e5. doi: 10.1016/j.fertnstert.2014.11.011

35. Hashimoto O, Moore RK, Shimasaki S. Posttranslational processing of mouse and human BMP-15: potential implication in the determination of ovulation quota. PNAS. 2005;102: 5426-31.

36. Dube JL, Wang P, Elvin J, Lyons KM, Celaste AJ, Matzuk MM. The bone morphogenetic protein 15 gene is X-linked and expressed in oocytes. Mol Endocrinol. 1998;12:1809-17.

37. Chand AL, Ponnanpolam A, Harris SE, Winship IM, Shelling AN. Mutational analysis of GDF-9 and BMP-15 as candidate genes in premature ovarian failure. Fertil Steril. 2006;86:100912. doi.10.1016/j.fertnstert.2006.02.107

38. Rah H, Joeon YJ, Ko JJ, Kim JH, Kim YR, Cha SH, et al. Association of inhibin $\alpha$ gene promoter polymorphisms with risk of idiopathic primary ovarian insufficiency in Korean women. Maturitas. 2014;77:163-7. doi: 10.1016/j.maturitas.2013.10.015

39. Robertson DM, Cahir N, Findlay JK, Burger HG, Groome N. Biological and immunological characterization of inhibin forms in human follicular fluid and plasma.J Clin Endocrinol. 1997;82:889-96.

40. Groswami D, Conway GS. POF. Human Reprod Update. 2005;11(4): 391-410. doi.10.1093/humupd/dmi012

41. De Mattos CS, Trevisan CM, Peluso C, Adami F, Cordis EB, Christofolini DM, et al. ESR1 and ESR2 gene polymorphisms are associated with human reproduction outcomes in Brazilian women. J Ovarian Res. 2014;7:114. doi: 10.1186/s13048-014-0114-2

42. Kolibianakis EM, Papanikolaou EG, Fatemi HM, Devroey P. Estrogen and folliculogenesis: is one necessary for the other? Curr Opin Obstet Gynecol. 2005;17:249-53.

43. Critchley HOD, Henderson TA, Kelly RW, Scobie GS, Evans LR, Groome NP, et al.Wild-type estrogen receptor (ER beta 1) and the splice variant (ER beta $\mathrm{cx} /$ beta2) are both expressed within the human endometrium throughout the normal menstrual cycle. J Clin Endocrinol. 2002 Nov 1;87(11):5265-73.

44. Gennari L, Merlotti D, De Paola V, Calabro A, Becherini L, Martini G, et al. Estrogen receptor gene polymorphisms and the genetics of osteoporosis. Am J Epidemiol. 2005 Feb 15;161 (4):307-20. 
45. Syrrou M, Georgiou I, Patsalis PC, Bouba I, Adonakis G, Pagoulatos GN. Fragile X premutations and (TA)n estrogen receptor polymorphism in women with ovarian dysfunction. Am J Med Genet. 1999;84:306-8.

46. Bretherick KL, Hanna CW, Currie LM, Fluker MR, Hammond GL, Robinson WP. Estrogen receptor alpha gene polymorphisms are associated with idiopathic premature ovarian failure. Fertil Steril. 2008;89:318-24. doi.10.1016/j.fertnstert.2007.03.008

47. Xita N, Georgiou I, Lazaros L, Psofaki V, Kolios G, Tsatsoulis A. The role of sex hormone-binding globulin and progesterone receptor gene variants in the development of polycystic ovary syndrome. Hum Reprod. 2008 Mar 1;23(3):693-8. doi: 10.1093 /humrep/dem 382 .

48. Ibanez L, Ong KK, Mongan N, Jaaskelainen J, Marcos MV, Hughes I, et al. Androgen receptor gene CAG repeat polymorphism in the development of ovarian hyperandrogenism. J Clin Endocrinol Metab. 2008;93(5):1935-45. doi.org/10.1210/jc. 2002-021791
49. Chatterjee S, Singh R, Kadam S, Maitra A, Thangaraj K, Meherji $\mathrm{P}$, et al. Longer $\mathrm{CAG}$ repeat length in the androgen receptor gene is associated with premature ovarian failure. Hum Reprod. 2009;24:3230-5. doi: 10.1093/humrep/dep296

50. Sugawa F, Wada Y, Maruyama T, Uchida H, Ishizuka B, Ogata T. Premature ovarian failure and androgen receptor gene CAG repeat lengths weighted by $\mathrm{X}$ chromosome inactivation patterns. Fertil Steril. 2009;91:649-52. doi: 10.1016/j.fertnstert. 2007.11.085

51. Panda B, Rao L, Tosh D, Dixit H, Padmalatha V, Kanakavalli M, et al. Germline study of AR gene of Indian women with ovarian failure. Gynecol Endocrinol. 2011;27:572-8. doi: 10.3109/09513590.2010.507282

52. Waggoner DD, Busit NR, Donnell GN. Long-term prognosis galactosaemia: results of a survey of 350 cases. J Inherit Metab Dis. 1990;13(6):802-18.

53. Forges T,Monnier-Barbarino P. Premature ovarian failure in galactosaemia: pathophysiology and clinical management. Pathol Biol. 2003;51(1):47-56.

Sažetak

\section{GENETSKA ETIOLOGIJA PRIJEVREMENE INSUFICIJENCIJE JAJNIKA}

\section{Franić-Ivaniševic, D. Franic, M. Ivovic, M. Tančić-Gajic, Lj. Marina, M. Barac i S. Vujović}

Primarna prijevremena insuficijencija jajnika (PPIJ) je sindrom koji je obilježen hipergonadotropnom amenorejom i hipoestrogenizmom. Incidencija PPIJ je 1:10.000 kod žena starosti 18-25 godina, 1:1000 kod žena starosti 25-30 godina i 1:100 kod žena starosti 35-40 godina. U 10\%-28\% slučajeva PPIJ je uzrok primarnih, a u 4\%-18\% sekundarnih amenoreja. Bolest nastaje kao posljedica ubrzanog procesa atrezije oocita, smanjenja broja germinativnih stanica i starenja središnjeg živčanog sustava. Specifični geni su odgovorni za kontrolu broja oocita koji prolaze proces ovulacije i vrijeme prekida reproduktivne funkcije. Pozitivna obiteljska anamneza PPIJ nađena je u oko 15\% žena s PPIJ, što ukazuje na postojanje određene genetske etiologije. Primarna insuficijencija jajnika (PIJ) dijeli se na primarnu i sekundarnu.U primarnu PIJ spadaju genetske aberacije vezane za kromosom X (monosomije, trisomije, translokacije, delecije) ili one vezane za autosomne kromosome. $U$ sekundarnu PIJ spadaju kirurško odstranjenje jajnika, liječenje kemoterapijom i radioterapijom te infekcije. Simptomi su razdražljivost, nemir, gubitak libida, depresija, nesanica, dekoncentracija, napadaji vrućine, povišenje tjelesne težine, suhoća vagine i drugih sluznica. Kriteriji za dijagnozu su folikulostimulirajući hormon viši od 40 IJ/L i estradiol (E2) niži od 50 $\mathrm{pmol} / \mathrm{L}$ kod žena mlađih od 40 godina.

Ključne riječi: Primarna insuficijencija ovarija - etiologija; Primarna insuficijencija ovarija - genetika 